\title{
HUBUNGAN ANTARA BEBERAPA KRITERIA KUALITAS DENGAN WARNA GULA AREN (Arenga pinnata Merr.)
}

\author{
Chindy Kalengkongan $^{1)}$, Julius Pontoh ${ }^{1)}$, Feti Fatimah ${ }^{1)}$ \\ ${ }^{1)}$ Program Studi Kimia FMIPA Unsrat, Manado \\ Jl. Kampus Unsrat, Manado 95115 \\ e-mail: shi_chindy@yahoo.co.id; pontohjulius@yahoo.com; fetysanusi@yahoo.com
}

\begin{abstract}
ABSTRAK
Telah dilakukan penelitian yang bertujuan untuk mengetahui hubungan antara beberapa kriteria kualitas gula aren dengan warna gula aren. Indeks warna gula aren dengan metode ICUMSA bervariasi dari 16932,53 sampai 87286,91 IU. Terdapat hubungan antara pengamatan warna secara visual dengan indeks warna yang ditentukan dengan metode ICUMSA dengan koefisien korelasi 0,821. Tidak terdapat hubungan antara kadar air dengan indeks warna gula aren. Terdapat hubungan antara $\mathrm{pH}$ dari gula dengan indeks warna dengan koefisien korelasi 0,771 dan terdapat hubungan antara kandungan gula reduksi dengan indeks warna dengan koefisien korelasi 0,884.
\end{abstract}

Kata Kunci: Gula Aren, Warna Gula Aren, Kadar Air, pH, Gula Pereduksi

\section{CORRELATION BETWEEN SEVERAL QUALITY CRITERIA AND COLOR PALM SUGAR (Arenga pinnata Merr.)}

\begin{abstract}
Research has been conductedthat aims to determine the relationship between several quality criterias of palm sugar and the color of palm sugar. Color index of palm sugar with ICUMSA method varies from 16932,53 to 87286,91 IU. There is a relationship between visual color with specified color index by ICUMSA method with a correlation coefficient by 0,821 . There is no relationship between the water content and the color index of palm sugar. There is a relationship between $\mathrm{pH}$ of the sugar and the color index by values 0,771 and there is a relationship between reducing sugar content and the color index with a correlation coefficient of 0,884 .
\end{abstract}

Keywords: Palm Sugar, Color of Palm Sugar, Moisture, $\mathrm{pH}$, reducing sugar

\section{PENDAHULUN}

Salah satu kriteria mutu gula aren yang telah ditetapkan oleh Standard Nasional Industri adalah warna gula. Mengenai warna gula palma, BSN (1995) telah menetapkan standar warna gula yaitu warna kuning kecokelatan sampai cokelat. Penetapan warna gula aren seperti di atas masih didasarkan pada penglihatan dengan mata. Dalam dunia industri hal ini masih kurang tepat oleh karena setiap orang mempunyai penafsiran yang berbeda-beda. Itulah sebabnya mengapa penetapan warna gula aren secara objektif perlu dilakukan (Pontoh, siap terbit).

Selain itu, parameter lain yang telah ditentukan oleh BSN (1995), yaitu gula pereduksi dan kadar air masing-masing maksimal $10 \%$. Adanya gula pereduksi dalam gula aren disebabkan adanya ragi yang menfermentasi sukrosa menjadi gula pereduksi. Semakin tinggi kandungan gula pereduksi dalam gula aren semakin kurang baik kualitas gula tersebut. Faktor lain yang mempengaruhi kualitas gula adalah $\mathrm{pH}$. Semakin rendah $\mathrm{pH}$, semakin rendah kualitas gula tersebut. Hal ini disebabkan oleh adanya mikroorganisme yang menyebabkan fermentasi lebih lanjut gula pereduksi menjadi asam-asam organik (Pontoh, siap terbit).

Menurut Duxbury (2005), salah satu faktor penting dalam penentuan kualitas pangan adalah warna. Penentuan warna makanan telah dikembangkan dengan berbagai metode dengan menggunakan berbagai peralatan seperti kolorimeter dan spektrofotometer (Duxbury, 2005 dan Pontoh, 
2013). Menurut Altenburg (2000), teknik pengujian warna gula menggunakan spektrofotometer dikenal dengan metode ICUMSA. ICUMSA (International Commision for Uniform Methods of Sugar Analysis) merupakan lembaga yang dibentuk untuk menyusun metode analisis kualitas gula. Mengenai warna gula, ICUMSA telah menetapkan kualitas warna gula. Menurut Altenburg (2000), metode pengujian warna gula dengan standar ICUMSA yaitu menggunakan spektrofotometer dengan panjang gelombang $420 \mathrm{~nm}$ dan $720 \mathrm{~nm}$. Pontoh (Siap terbit) telah mengembangkan metode analisa warna untuk gula aren dengan metode ICUMSA. Namun sampai saat ini belum ada laporan yang menghubungkan kualitas warna gula aren dengan parameter kualitas gula aren lainnya seperti kadar air, $\mathrm{pH}$ dan gula pereduksi.

\section{METODOLOGI PENELITIAN}

Penelitian ini dilakukan di laboratorium Advance Universitas Sam Ratulangi Manado dan di laboratoriun Teknologi Industri Institut Teknologi Minaesa Tomohon selama bulan Juni-Juli 2013.

Dalam penelitian ini digunakan sebanyak delapan sampel gula aren yang beredar di pasar kota Manado yaitu pasar Karombasan dan pasar Bersehati.

\subsection{Alat dan Bahan}

Alat-alat yang digunakan adalah labu takar, gelas ukur, pipet, sudip, erlenmeyer, buret, timbangan digital, oven, stirer, $\mathrm{pH}$ meter, desikator, stopwatch dan spektrofotometer Genesis 20.

Bahan-bahan yang digunakan dalam penelitian ini adalah sampel gula aren yang beredar di pasaran kota Manado, aquades; $\mathrm{HCl} ; \quad \mathrm{NaOH} ; \quad \mathrm{CuSO}_{4} ; \quad \mathrm{NaOH} ; \mathrm{NaOH}$ $20 \%$;NaK-tartrat; $\mathrm{HCl} 6,76 \% ; 0,5 \mathrm{~N} \mathrm{HCl}$; larutan buffer $\mathrm{pH} 4$; larutan buffer $\mathrm{pH} 6,8$; indikator phenolphthalein $1 \%$ dan indikator methylene blue $2 \%$; reagensia soxhlet $\left(\mathrm{CuSO}_{4}\right.$ ditambah NaK-tartrat dengan perbandingan $1: 1$ ).

\subsection{Metode Penelitian}

\section{a. Analisa Kadar Air (AOAC,1999)}

Sebanyak 2-5 g sampel dimasukkan ke dalam cawan yang telah diketahui bobotnya. Cawan yang berisi sampel tersebut dipanaskan pada suhu $100-105^{\circ} \mathrm{C}$ selama tiga jam, kemudian didinginkan di dalam desikator selama 30 menit dan ditimbang. Perlakuan ini diulang sampai mencapai bobot konstan. Sisa sampel dihitung sebagai total padatan dan bobot yang hilang sebagai air. Kadar air dihitung dengan rumus sebagai berikut:

Kadar air $(\%)=\frac{\text { berat awal-berat akhir }}{\text { berat sampel }} \times 100 \%$

\section{b. Pengukuran pH (BSES, 1991)}

$\mathrm{pH}$ meter dikalibrasi dengan menggunakan larutan buffer $\mathrm{pH} 4$ dan $\mathrm{pH} 6,8$. Ditimbang $10 \mathrm{~g}$ sampel lalu diencerkan dalam aquades sampai $100 \mathrm{~mL}$. $\mathrm{pH}$ larutan sampel diukur dengan menggunakan $\mathrm{pH}$ meter yang telah dikalibrasi. Elektroda diangkat dari larutan sampel dan kemudian dicuci dengan air. Saat tidak digunakan elektroda harus diredam dengan air.

\section{c. Penentuan gula pereduksi dengan metode Lane-Eynon (BSES, 1991)}

$10 \mathrm{~g}$ sampel dilarutkan dalam aquades sampai $100 \mathrm{~mL}$. Dituang $10 \mathrm{~mL}$ reagensia soxhlet kedalam erlenmeyer 250 $\mathrm{mL}$. Larutan sampel diisi kedalam buret kemudian larutan sampel tersebut dititrasi kedalam erlenmeyer sebanyak $15 \mathrm{~mL}$. Lalu dipanaskan sampai mendidih, pendidihan diteruskan selama 15 detik dan di tambahkan tetes demi tetes larutan sampel kedalam erlenmeyer yang berisi regensia soxhlet sampai warna biru hilang. Kemudian ditambahkan $1 \mathrm{~mL}$ larutan indikator methylene blue $0,2 \%$ dan larutan sampel dititrasikan kedalam erlenmeyer yang berisi regensia soxhlet sampai warna biru hilang. Dicatat berapa banyak larutan sampel yang terpakai pada saat titrasi. Dihitung kadar gula invert sebelum inversi per $100 \mathrm{~mL}$ larutan sampel (dalam \%).

$\underset{100}{\operatorname{Kadar} \operatorname{gula}(\%)}=\mathrm{G} x$

$\overline{\mathrm{m} / \text { faktorpengenceran } \mathrm{x} 1000}$ 
Dimana:

$\mathrm{G}=$ total gula yang dibutuhkan untuk ereduksi reagensiasoxhlet (mg). Dilihat dalam tabel Lane-Eynon sesuai dengan volume titran yang dipakai.

$\mathrm{M}=$ berat sampel (mg)

\section{d. Analisa warna (BSES, 1991)}

Analisis warna dilakukan dengan menggunakan mata telanjang (visual) dan metode ICUMSA. Pengamatan visual dilakukan dengan melihat penampakan warna gula mulai dari yang berwarna kuning muda kecokelatan sampai hitam kecokelatan.

Penentuan indeks warna gula dilakukan dengan mengambil $0,6 \mathrm{~g}$ sampel gula selanjutnya dilarutkan dalam aquades sebanyak $40 \mathrm{~mL}$. Larutan sampel tersebut ditambahkan aquades sampai $100 \mathrm{~mL}$. Kemudian larutan tersebut dituang kedalam wadah gelas kimia. Dipastikan $\mathrm{pH}$ meter dalam keadaan yang bersih dan telah dikalibrasi pada larutan buffer $\mathrm{pH} 4$ dan $\mathrm{pH}$ 6,8. $\mathrm{pH}$ larutan sampel diatur sampai 7 dengan menambahkan $0,1 \mathrm{M} \mathrm{HCl}$ atau $0,1 \mathrm{M}$
$\mathrm{NaOH}$. Larutan tersebut diaduk dengan stirer magnetik selama $\mathrm{pH}$ larutan diatur. Kemudian dibaca absorbansinya pada spektrofotometer dengan panjang gelombang $420 \mathrm{~nm}$ dan $720 \mathrm{~nm}$. Indeks warna larutan sampel dapat dihitung dengan rumus sebagai berikut:

Indeks warna $=\mathrm{a}^{*}{ }_{420}-2 \mathrm{a}{ }_{720}$

Dimana $a^{*}=\frac{\mathrm{A} \times 1000}{\mathrm{bc}}$

$$
\begin{aligned}
& \mathrm{A}=\text { absorban } \\
& \mathrm{b}=\text { panjang sel }(\mathrm{cm}) \\
& \mathrm{c}=\text { konsentrasi }(\mathrm{g} / \mathrm{mL})
\end{aligned}
$$

\section{HASIL DAN PEMBAHASAN}

\subsection{Warna Visual dan Indeks Warna}

Penelitian ini diambil delapan sampel gula aren yang berasal dari beberapa pasar yang beredar di Kota Manado dan dari berbagai tempat pembuatan yang berbeda-

\begin{tabular}{|c|c|c|c|}
\hline Sampel & Asal & Warna visual & Indeks warna (IU) \\
\hline & $\begin{array}{l}\text { Berasal dari pasar Bersehati } \\
\text { diproduksi di Motoling }\end{array}$ & Kuning muda kecokelatan & 16932,53 \\
\hline L & $\begin{array}{c}\text { Berasal dari pasar Karombasan } \\
\text { diproduksi di Tomohon }\end{array}$ & Kuning kecokelatan & 29958,59 \\
\hline & $\begin{array}{c}\text { Berasal dari pasar Bersehati } \\
\text { diproduksi di Ratahan }\end{array}$ & Kuning tua kecokelatan & 21945,42 \\
\hline & $\begin{array}{l}\text { Berasal dari pasar Karombasan } \\
\text { diproduksi di Tomohon }\end{array}$ & Cokelat muda & 20301,05 \\
\hline & $\begin{array}{l}\text { Berasal dari pasar Bersehati } \\
\text { diproduksi di Motoling }\end{array}$ & Cokelat tua & 45279,69 \\
\hline & $\begin{array}{c}\text { Berasal dari pasar Karombasan } \\
\text { diproduksi di Ratahan }\end{array}$ & Cokelat kehitaman & 73377,48 \\
\hline II & $\begin{array}{l}\text { Berasal dari pasar Bersehati } \\
\text { diproduksi di Motoling }\end{array}$ & Cokelat tua kehitaman & 62845,04 \\
\hline & $\begin{array}{l}\text { Berasal dari pasar Bersehati } \\
\text { diproduksi di Motoling }\end{array}$ & Hitam kecokelatan & 87286,91 \\
\hline
\end{tabular}
beda.

Tabel 1. Asal sampel gula aren dan hasil pengukuran indeks warna. 
Berdasarkan data yang ada pada Tabel 1 sampel gula disusun berdasarkan intensitas warna secara visual, mulai dari yang berwarna terang sampai berwarna gelap.
Berdasarkan penelitian indeks warna yang diperoleh menunjukan adanya hubungan antara warna visual dan indeks warna sebagaimana yang tertera pada Gambar 1.

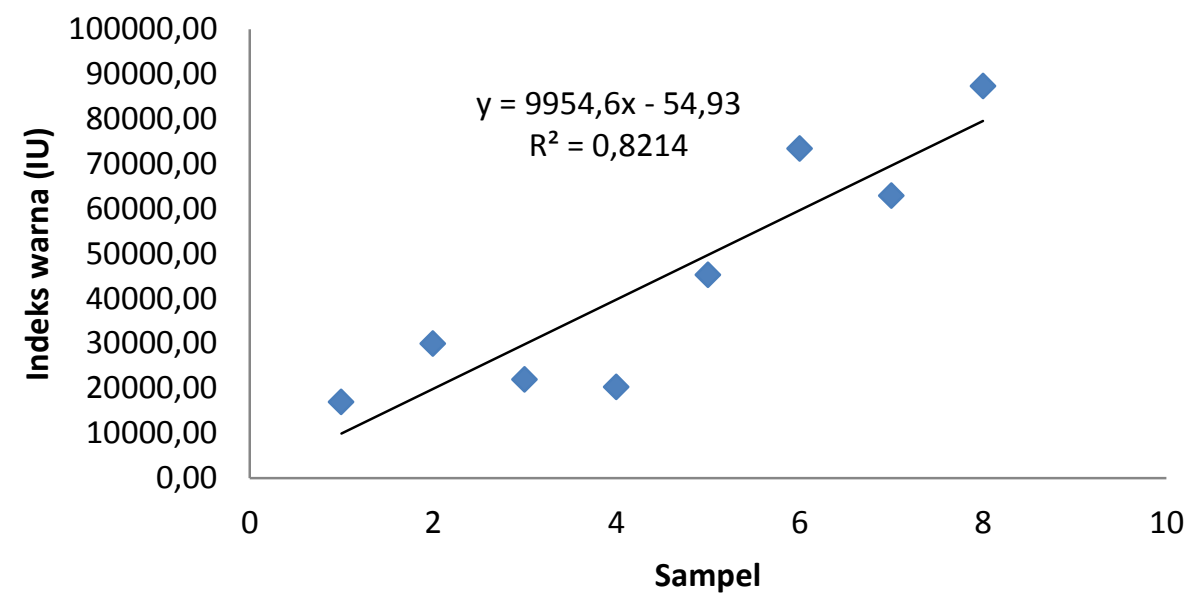

Gambar 1. Hubungan antara warna visual dengan indeks warna.

Berdasarkan Gambar 1 terlihat bahwa sampel gula yang disusun secara visual berbanding lurus dengan indeks warna yang diperoleh, dimana semakin gelap warna gula semakin tinggi indeks warna yang diperoleh. Pembentukan warna yang terjadi pada gula aren disebabkan adanya reaksi maillard (browing) yang menghasilkan senyawa cokelat (Winarno, 2008). Reaksi maillard akan lebih cepat terjadi pada suasana basa (Shallenberger dan Birch dalam Ardiansah, 2007). Menurut Kusnandar (2010), faktor penting yang terlibat dalam reaksi maillard adalah gula pereduksi dan $\mathrm{pH}$.

\subsection{Kadar air}

Menurut Pontoh (2013), penentuan kadar air yang terkandung pada gula aren dimaksudkan untuk mengetahui kandungan padatan yang terkandung pada gula aren sehingga akan mempermudah perhitungan kandungan sukrosa dan gula pereduksi. Dari hasil penelitian diperoleh kadar air dari berbagai gula aren sebagaimana yang tercantum pada Tabel 2.
Tabel 2. Kadar air dari berbagai gula aren

\begin{tabular}{|c|c|}
\hline Indeks warna & Kadar air (\%) \\
\hline 16933 & 11,99 \\
\hline 29959 & 12,47 \\
\hline 21945 & 12,37 \\
\hline 20301 & 11,83 \\
\hline 45280 & 12,30 \\
\hline 73377 & 12,64 \\
\hline 62845 & 11,64 \\
\hline 87287 & 11,87 \\
\hline
\end{tabular}

Berdasarkan data yang ada pada Tabel 2 menunjukan bahwa kandungan air dari berbagai gula aren yang sangat bervariasi mulai dari $11,64 \%$ sampai $12,64 \%$. Berdasarkan ketentuan Standard Nasional Industri bahwa kadar air untuk gula palma cetakan maksimal $10 \%$. Dari keseluruhan sampel yang ada, kadar airnya berkisar lebih dari $10 \%$. Tingginya kadar air yang terkandung pada gula aren dapat disebabkan oleh kondisi nira aren sebagai bahan baku. Hal ini sesuai dengan pendapat Baharuddin et al. (2007), bahwa kondisi nira aren yang langsung di olah lebih baik dari nira aren yang telah mengalami proses penyimpanan.

Hasil penelitian menunjukan hubungan antara warna dan kadar air dapat dilihat pada Gambar 2 di bawah ini. 


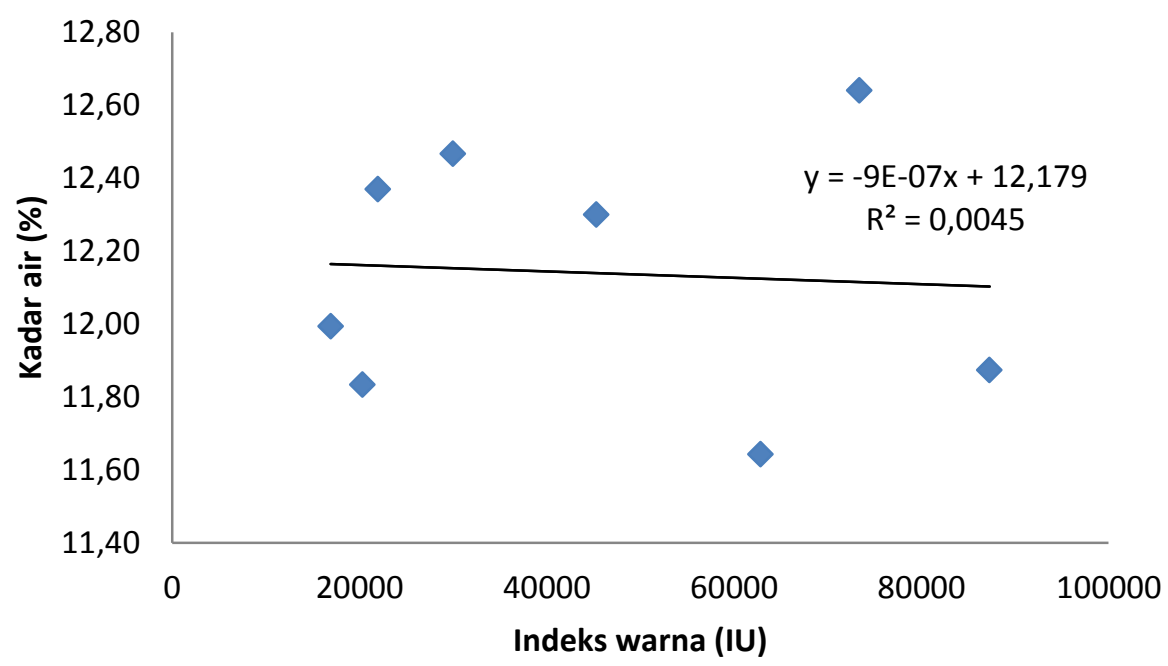

Gambar 2. Hubungan antara indeks warna dengan kadar air dalam gula aren.

Dari Gambar 2 dapat dilihat bahwa tidak ada hubungan antara indeks warna dengan kadar air. Hal ini ditunjukan oleh koefisien korelasi yang sangat rendah $(0,004)$ antara indeks warna dengan kadar air.

\subsection{Derajat keasaman gula aren $(\mathrm{pH})$}

Hasil penelitian derajat keasaman gula dari berbagai gula aren dapat dilihat pada Tabel 3.

Tabel 3. Hasil pengukuran $\mathrm{pH}$ dari berbagai gula aren.

\begin{tabular}{|c|c|}
\hline Indeks warna & $\mathrm{pH}$ \\
\hline 16933 & 5,92 \\
\hline 29959 & 5,44 \\
\hline 21945 & 5,08 \\
\hline 20301 & 5,28 \\
\hline 45280 & 4,68 \\
\hline 73377 & 4,35 \\
\hline 62845 & 4,37 \\
\hline 87287 & 4,40 \\
\hline
\end{tabular}

Berdasarkan data yang ada pada Tabel $3 \mathrm{pH}$ gula aren bervariasi mulai dari 4,35 sampai 5,91. $\mathrm{pH}$ gula aren yang paling rendah yaitu pada sampel gula nomor VI sedangkan $\mathrm{pH}$ gula aren yang paling tinggi yaitu pada sampel nomor I. Sejauh ini persyaratan mengenai $\mathrm{pH}$ pada gula aren belum ditentukan oleh Standart Industri Nasional sehingga lewat penelitian ini bisa membantu pihak yang berwenang untuk menetapkan standar $\mathrm{pH}$ untuk produk gula aren. Nurlela (2002), melaporkan bahwa kondisi keasaman nira sangat berperan dalam pembentukan warna gula.

Untuk melihat hubungan antara $\mathrm{pH}$ dan indeks warna dalam gula aren dapat dilihat pada Gambar 3.

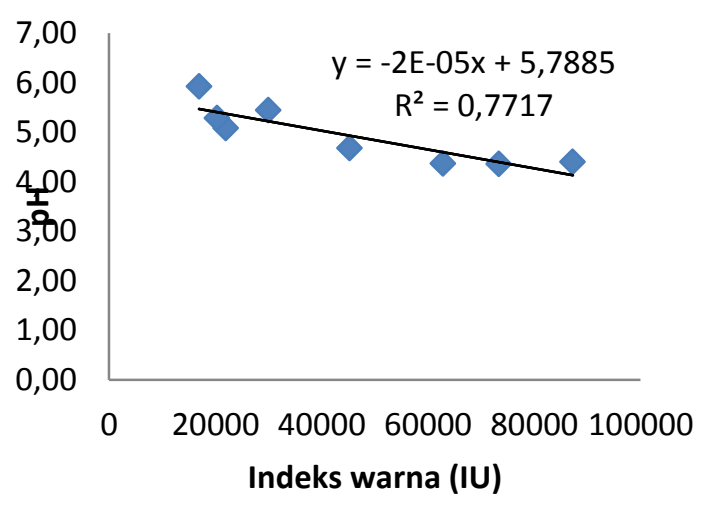

Gambar 3. Hubungan antara indeks warna dan $\mathrm{pH}$ pada gula aren.

Dari Gambar 3 dapat dilihat bahwa ada hubungan yang negatif antara $\mathrm{pH}$ dengan indeks warna dengan koefisien korelasi yang cukup kuat $(0,771)$. Data ini menunjukan bahwa semakin tinggi indeks warna, semakin rendah $\mathrm{pH}$. Kondisi $\mathrm{pH}$ gula aren disebabkan oleh kondisi bahan baku (nira) mulai dari 
penyadapan sampai pada proses pemasakan untuk menghasilkan produk gula aren. Hal ini sesuai dengan pendapat Nurlela (2002), bahwa kondisi keasaman nira sangat berperan dalam pembentukan warna gula.Dengan demikian, kondisi bahan baku (nira) dapat dijadikan sebagai indikasi pembentukan warna gula aren.

\subsection{Kandungan gula pereduksi pada gula aren}

Hasil penelitian kandungan gula pereduksi dari berbagai gula aren dapat dilihat pada Tabel 4.

Tabel 4. Kandungan gula pereduksi (\%) dari berbagai gula aren

\begin{tabular}{|c|c|}
\hline $\begin{array}{c}\text { Indeks } \\
\text { warna }\end{array}$ & $\begin{array}{c}\text { Kandungan gula } \\
\text { pereduksi }(\%)\end{array}$ \\
\hline 16932,53 & 2,92 \\
\hline 29958,59 & 5,23 \\
\hline 21945,42 & 4,17 \\
\hline 20301,05 & 3,25 \\
\hline 45279,69 & 7,77 \\
\hline 73377,48 & 8,10 \\
\hline 62845,04 & 9,90 \\
\hline 87286,91 & 14,92 \\
\hline
\end{tabular}

Berdasarkan data yang ada pada Tabel 4 dapat dilihat bahwa kandungan gula pereduksi bervariasi mulai dari $2,92 \%$ sampai $14,92 \%$. Kandungan gula pereduksi yang paling rendah yaitu pada sampel nomor I sedangkan kandungan gula pereduksi yang paling tinggi yaitu pada sampel nomor VIII. Berdasarkan ketentuan Standar Nasional Industri bahwa kandungan gula pereduksi untuk gula cetak maksimal $10 \%$. Dari kedelapan sampel, kandungan gula pereduksi yang lebih dari $10 \%$ adalah sampel VIII. Tingginya kadar gula pereduksi dapat disebabkan oleh perlakuan bahan baku (nira) yang terkontaminasi baik dari penyadapan nira sampai pada proses pengolahan produk gula. Kadar gula pereduksi yang terkandung pada gula aren sangat menentukan kualitas gula aren. Hal ini sesuai dengan pendapat yang dikemukakan oleh Baharuddin et al. (2007), bahwa semakin rendah kadar gula pereduksi maka semakin bagus kualitas gula tersebut demikian pula sebaliknya semakin tinggi kadar gula reduksinya maka semakin rendah kualitas gula tersebut. Menurut Sardjono et al. dalam Baharuddin et al. (2007), kadar gula pereduksi mempengaruhi warna gula dimana makin rendah kadar gula pereduksinya maka makin terang warna gula tersebut, sebaliknya makin tinggi kadar gula pereduksinya makin gelap warna gula tersebut.

Hasil penelitian menunjukan adanya hubungan antara gula pereduksi dan indeks warna dalam gula aren. Dapat dilihat pada Gambar 4 di bawah ini.

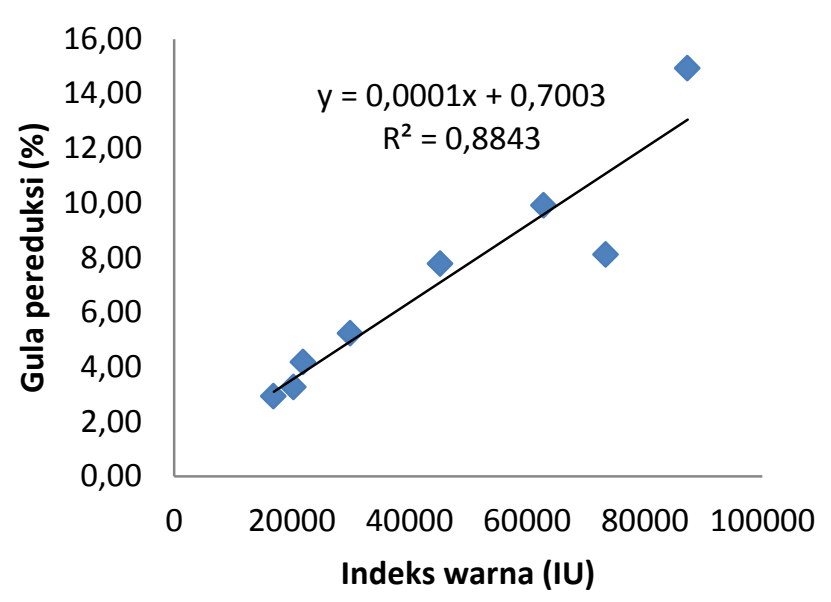

Gambar 4. Hubungan antara indeks warna dan gula pereduksi pada gula aren.

Dari Gambar 4 dapat dilihat bahwa ada hubungan antara gula pereduksi dengan indeks warna dengan koefisien korelasi yang cukup kuat yaitu 0,884 . Data ini menunjukan bahwa semakin tinggi indeks warna, semakin tinggi kandungan gula pereduksinya. Kadar gula pereduksi mempengaruhi warna gula di mana makin rendah kadar gula pereduksinya makin terang warna gulanya, sebaliknya makin tinggi kadar gula pereduksinya makin gelap warna gula tersebut (Sardjono et al. dalam Baharuddin et al., 2007).

\section{KESIMPULAN}

Berdasarkan hasil penelitian yang dilakukan dapat disimpulkan bahwa terdapat hubungan antara warna gula aren yang disusun secara visual dengan indeks warna menggunakan metode ICUMSA. Terdapat hubungan antara $\mathrm{pH}$ dan gula pereduksi dengan warna gula aren masing-masing dengan koefisien korelasi 0,771 dan 0,884. 
Tidak terdapat hubungan antara kadar air dengan warna gula aren dengan koefisian korelasi 0,004 .

\section{DAFTAR PUSTAKA}

Altenburg, W. 2000. The Analysis of Sugar and Molasses. John Wiley \& Sons, New York.

Ardiansah, A. 2007. Optimasi karbonatasi untuk pemucatan raw sugar dengan menggunakan reaktor venturi bersirkulasi [Skripsi]. Fakultas Teknologi Pertanian IPB, Bogor.

Association of Official Analytical Chemist [AOAC]. 1999. Official Methods of Analysis of Association of Official Analitical Chemists. Edisi ke-15. Kenneth Helrich, Chapter 44.1.03, United States of America.

Badan Standarisasi Nasional [BSN].1995. Gula Palma. Badan Standarisasi Nasional, Jakarta.

Baharuddin., M. Muin., dan H. Bandaso. 2007. Pemanfaatan nira aren (Arenga pinnata Merr.) sebagai bahan pembuatan gula putih kistal. $J$. Perennial. 3: 40-43.
Bureau Measuring Food color of Sugar Experimental Stations [BSES]. 1991. The Standard Laboratory Manual for Australian Sugar Mills. Bureau of Sugar Experimental Stations [BSES]. Australia.

Duxbury, D. 2005. [Artikel ilmiah]. Institute of Food Technologists, Amerika.

Kusnandar, F. 2010. Kimia Pangan Komponen makro. Dian Rakyat, Jakarta.

Nurlela, E. 2002. Kajian faktor-faktor yang mempengaruhi pembentukan warna gula merah [Skripsi]. Fakultas Teknologi Pertanian IPB, Bogor.

Pontoh, J. 2013. Penentuan kandungan sukrosa pada gula aren dengan metode enzimatik. J. Chem. Prog. 6: 26-33.

Pontoh, J. Pengembangan Metode Analisa Warna Gula Aren. (Siap terbit).

Winarno, F. G. 2008. Kimia pangan dan gizi. Gramedia, Jakarta. 